\title{
DETERMINANT TAX AVOIDANCE IN BASIC AND CHEMICAL INDUSTRY MANUFACTURING COMPANIES LISTED ON THE IDX
}

\author{
Hamilah and Kenny F. Situmorang \\ Y.A.I School Of Ekonomic. Jakarta, Indonesia \\ E-mail : hamilah.tiyan@gmail.com
}

\begin{abstract}
Profitability is one factor to attribute the company's financial condition to tax avoidance. Leverage is a ratio to measure a company's ability to pay all its liabilities both short-term and long-term. In addition to profitability and leverage, sales growth can also affect tax avoidance activities. By measuring the sales growth of a company can predict how much profit it earns so that the company will tend to practice tax avoidance. The purpose of this research is to build a theory that serves to explain a relationship. The relationship used is a causal relationship that influences variables and other variables. The study uses quantitative research methods with a causal descriptive and associative approach to determine the influence between two or more variables. The test results showed that returns on assets, debt to equity ratio, and sales growth affected the cash effective tax rate.f research
\end{abstract}

Keywords: Profitability; Leverage; Sales Growth; Tax Avoidance

\section{DETERMINAN DARI PENGHINDARAN PAJAK PADA PERUSAHAAN MANUFAKTUR SEKTOR INDUSTRI DASAR DAN KIMIA YANG TERDAFTAR DI BEI}

\begin{abstract}
ABSTRAK. Profitabilitas merupakan salah satu faktor untuk mengaitkan kondisi keuangan perusahaan terhadap penghindaran pajak. Leverage adalah rasio untuk mengukur kemampuan perusahaan dalam membayar seluruh kewajibannya baik jangka pendek maupun jangka panjang. Selain profitabilitas dan leverage, pertumbuhan penjualan juga dapat mempengaruhi aktivitas penghindaran pajak. Dengan mengukur pertumbuhan penjualan suatu perusahaan dapat memprediksi seberapa besar profit yang di peroleh sehingga perusahaan akan cenderung untuk melakukan praktik tax avoidance Tujuan penelitian ini adalah membangun suatu teori yang berfungsi untuk menjelaskan suatu hubungan, hubungan yang digunakan adalah hubungan kausal yaitu hubungan yang mempunyai pengaruh antara variable satu dengan variabel lainnya. Penelitian ini menggunakan metode penelitian kuantitatif dengan pendekatan deskriptif dan assosiatif kausal yang bertujuan untuk mengetahui pengaruh antara dua variabel atau lebih. Hasil pengujian menunjukan bahwa return on asset, debt to equity ratio dan pertumbuhgan penjualan secara bersama-sama berpengaruh terhadap cash effective tax rate.
\end{abstract}

Kata Kunci: Profitabilitas; Leverage; Pertumbuhan Penjualan; Penghindaran Pajak

\section{INTRODUCTION}

In Indonesia, 3 tax collection systems apply based on laws and regulations, including the self-assessment system. The system gives the taxpayer (WP) authority to process their taxation, such as calculating, paying, and reporting the tax amount owed by regulations. Taxation that applies in Indonesia, besides that the objective of implementing this tax collection system is to facilitate the community and build a sense of national independence in carrying out its tax obligations. However, this system can also lead to taxpayers' irregularities not to report their tax obligations correctly (Dimitrios, Helen, \& Mike, 2016).

Irregularities are able to occur because of tax between the different interests and must task at states eyes, sources of income tax is significantly will contribute to government financing (Fernandes, Lynch, \& Netemeyer, 2014).

In contrast, tax for companies as taxpayers is a burden that will reduce net income. Companies try to pay taxes with the smallest amount possible, while the state tries to generate the optimal revenue from tax sources. Based on these differences of interest, taxpayers tend to reduce the number of tax payments that should be owed, whether legally or illegally. Efforts to reduce tax payments legally are called tax avoidance (Reschiwati, Limakrisna, Sayekti, \& Purnamasari, 2019).

In general, taxpayers will tend to choose to do tax avoidance instead of tax evasion because tax evasion is a legal crime in the field of illegal taxation. In contrast, tax avoidance is a way of saving taxes by still complying with the provisions of applicable tax regulations by exploiting loopholes in these regulations. Avoid itself can be complicated problem because tax increase, on the one hand, evade taxes allowed but on the other hand undesirable avoid tax (Australian Bureau of Statistics, 2016).

Profitability is one factor to link the company's financial condition to tax avoidance. Profitability is the description of the company ability to produce an advantage in a certain period of time. There are 
various ways to measure the profitability ratio, one of which is the return on assets (ROA) (Aulia, 2016) Financing to Deposit Ratio (FDR.

ROA serves to measure a company ability to produce the first projected future. Better value ROA the greater the benefits obtained to manage a better worth of the company assets. When profits get more significant, the amount of income tax will increase according to the company's increase. Company with profitability tend to do avoid high tax burden to reduce the amount of tax paid to the state treasury (Simatupang \& Franzlay, 2016).

This company evade taxes can be seen from the company policies funding. In general, company activities are funded by two primary sources, namely from shareholders (equity financing) and debt (debt financing). Determining the source of funding is also a mode for taxpayers to reduce the tax burden. This is driven by tax treatment differences between interest payments as a cost of capital originating from debt and dividend payments as a cost of capital from issuing shares (Grant, 2003).

By the provisions of article 6 verse (1) letter a number of income tax law (3), income tax law payment of interest include the allowed to reduce the income that, so dirty on the other of dividend payments could not be paid for by article 9 verse (1) the letters of the law income tax (Dimitrios et al., 2016).

Therefore, taxpayers will tend to use debt as a funding source rather than issuing shares. In tax terminology, this effort is called thin capitalization, which is one way to tax avoidance (Reschiwati et al., 2019).

By choosing debt, the company is burdened with paying interest expenses. The company's interest expense will be a deduction for the company's net profit, which will later reduce tax payments to achieve maximum profit. The taxable profit of companies that use debt as a source of funding tends to be smaller than the source of funding from the issuance of shares to be classified as tax avoidance (Adelina, 2012). The higher the level of debt, it is indicated that the higher the company is doing tax avoidance. The purpose of tax avoidance is that the company diverts funds that should be used to pay corporate taxes to pay the debt itself (Vatansever \& Hepsen, 2015)the loan portfolio represents an important component of a bank's total assets. These assets generate huge interest income which is a critical measure of the bank's financial performance and stability. Therefore, the nonperforming loan ratio is a critical tool to measure a bank's performance. There is recently a growing recognition between macroeconomic indicators, bank-level factors and the non-performing loans (NPLs.

Leverage ratio is to measure the ability of the company to pay the entire 's, their obligations well. Short and long one way to measure the leverage debt to equity ratio the ratio (DER). DER is one of the ratio is used for measuring the degree ' $\mathrm{s}$ solvency, a company where it is the ratio which used to measure how much is owed to the total equity (Makri, Tsagkanos, \& Bellas, 2014)just before the beginning of the recession. In our days, Eurozone is in the middle of an unprecedented financial crisis, calling into question the soundness of the banking systems of European countries. Looking at both macrovariables (e.g. annual percentage growth rate of gross domestic product, public debt as $\%$ of gross domestic product, unemployment.

Apart from profitability and leverage, sales growth can also influence tax avoidance activities. It can be enough to optimize the use of existing resources in terms of sales from the previous year. Sales growth an important role in forming working capital management. This research used by the author is sales growth was because sales growth can explain either a good or not quite the company sales with measure the growth company sales. This system also can predict how much profit will get to practice so that the company would tend to evade taxes (Kostini, Dai, \& Oktaviani, 2017).

The phenomenon of tax avoidance practices that occurred in Indonesia was published in the online news http://www.merdeka.com on 27 August 2013, where there were thousands of multinational companies that did not carry out their tax obligations to the state. He said nearly 4,000 companies did not pay their taxes for seven years (Reschiwati et al., 2019).

Another tax-avoidance phenomenon occurred in 2013, namely the discovery of one case of tax avoidance committed by property developers.

\section{Tax evasion}

Tax avoidance is legal action. It can be justified because there are no binding rules. Tax avoidance only takes advantage of loopholes in tax regulations that have been regulated by the government. The company's tax avoidance goal is to reduce or minimize the amount of tax owed to be paid to the state treasury (Fitriyanti, Fauzi, \& Armeliza, 2017).

According to (Stavins, 2000), tax evasion is the effort to reduce the tax with law do with it according to (Dimitrios et al., 2016), tax evasion is the effort to evade taxes by legal and safe for taxpayers without conflict with the tax effect where methods 
and techniques used inclined to take advantage of weakness contained in law. Tax regulation itself to reduce the amount of tax owed.

There are many measurements in measuring evade taxes, including applying the tax rate effective (ETR), cash (CTR) tax rates effective, and current tax rates effective (CUETR), from three measurements. Evade taxes in this study measured by cash tax rates effective (ETR) cash. ETR cash really cash issued for the cost of tax divided by its earnings before the tax (Zango, Kamardin, \& Ishak, 2015)it requires strict adherence to standard regulations that is effective both in monitoring and enforcement. In recognition, the IASB rolled out three different but inter-related standards (IFRS 7- financial instruments disclosure, IFRS 9-financial instruments recognition and measurement and IAS 32-financial instruments presentation. Tax the measurement of use cash ETR according to Dyreng et al (2008), suitable to describe activities tax evasion by companies because cash ETR not affected by estimate judgment protection allowance or tax. Cash money actually ETR reflect level apply to the taxpayer income, Who views based on the amount of tax paid (Muriithi, Wanjau, \& Omondi, 2018).

\section{Profitability}

Every company has the same goal of making a profit. The company's management makes every effort to determine policies that can bring the company according to its expectations. According to (Erlangga \& Mawardi, 2016)liquidity, capital adequacy and financing fraud on Sharia Bank profitability in Indonesia by January 2010 until December 2014 period. Research using purposive sampling method for taking samples. Data obtained based on Bank of Indonesia published viaWebsite realtime, obtained 60 samples. Research variables consisted of four independent variables and 1 dependent variable. Data analysing technique to answer research problem and examine research hypothesis using Double Linear Regression Analysis that supported by SPSS Statistics version 20 application. Based on the research, known that the effect of firm size (asset total, the ratio of advantage is its ability to profit for sale, assets and this capital with long-term investors will be interested in this analysis Good profitability.

Profitability is one factor to link the company's financial condition to tax avoidance. Profitability is the description of the company ability to produce an advantage in a certain period of time. There are various ways to measure the profitability ratio, one of which is the return on assets (ROA) (Aulia, 2016) Financing to Deposit Ratio (FDR.
ROA serves to measure a company ability to produce the first projected future. Better value ROA the greater the benefits obtained to manage a better worth of the company assets. When profits get more significant, the amount of income tax will increase according to the company's increase. Company with profitability tend to do avoid high tax burden to reduce the amount of tax paid to the state treasury (Simatupang \& Franzlay, 2016).

\section{Leverage}

According to (Nelson, 2014), the ratio increased a ratio describing the relationship between debt and capital, this ratio measure how much companies financed by obligation or external sides with described by capital, according to the (Rampini \& Viswanathan, 2013) the leverage is used to measure the extent to which the company assets are funded. Debt rasio is used for measuring its ability to pay for all both short term and long term debts / total assets.

In practice, to cover the shortage of the needed funds, the company has several sources of funds that can be used one financial resources used is capital loans debt. Capital debt relatively not limited and motivate management to work more creative and active in, because should pay their obligations dangerous products (Fernandes et al., 2014). Instrument is used in analyze financial report to show the amount of collateral to creditors available.

The definition of influence above shows that the impact of is a company's ability to pay all their obligations, short-term and long-term also obligations. From the leverage ratio, it can also be seen that whether the company is funded using more liabilities or capital originating from shareholders or other sources, namely debt. The higher the leverage level of a company, the greater the agency cost will be. The large degree of leverage ratio casts doubt on its ability to sustain its business in the future. This is because most of the company's funds will be used to finance debt so that the funds to operate will decrease (Kraak et al., 2012).

Leverage ratio is to measure the ability of the company to pay the entire ' $\mathrm{s}$, their obligations well. Short and long one way to measure the leverage debt to equity ratio the ratio (DER). DER is one of the ratio is used for measuring the degree ' $\mathrm{s}$ solvency, a company where it is the ratio which used to measure how much is owed to the total equity (Makri, Tsagkanos, \& Bellas, 2014)just before the beginning of the recession. In our days, Eurozone is in the middle of an unprecedented financial crisis, calling into question the soundness of the banking systems of European countries. Looking at both macro- 
variables (e.g. annual percentage growth rate of gross domestic product, public debt as \% of gross domestic product, unemployment.

Apart from profitability and leverage, sales growth can also influence tax avoidance activities. It can be enough to optimize the use of existing resources in terms of sales from the previous year. Sales growth an important role in forming working capital management. This research used by the author is sales growth was because sales growth can explain either a good or not quite the company sales with measure the growth company sales. This system also can predict how much profit will get to practice so that the company would tend to evade taxes (Kostini, Dai, \& Oktaviani, 2017).

\section{Sales Growth}

According to (Walter, Auer, \& Ritter, 2006), sales growth is an important indicator of the market acceptance of products and service. So will obtained amount of income resulting from the sale could be used to measure the growth rates sales. Sales growth reflect the past investment successes and can be used as a prediction growth. For the growth sales is also an indicator of a company's demand and competitiveness in the industry.

Apart from profitability and leverage, sales growth can also influence tax avoidance activities. It can be enough to optimize the use of existing resources in terms of sales from the previous year. Sales growth an important role in forming working capital management. This research used by the author is sales growth was because sales growth can explain either a good or not quite the company sales with measure the growth company sales. This system also can predict how much profit will get to practice so that the company would tend to evade taxes (Kostini, Dai, \& Oktaviani, 2017).

From the theoretical basis above, the research design can be described as follows:

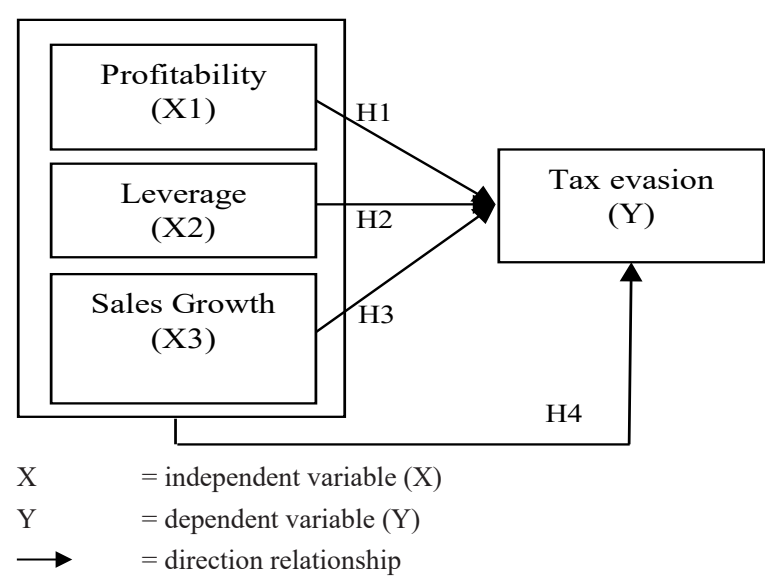

\section{METHODS}

A method that research activities using methods to get data, systematic which includes, data collection data processing, and data analysis show that the researh methods that a scientific way to get data to a particular purpose and menggunakan.sebuah suitable and appropriate methods to the problem under still need to be for the assessment (Sugiyono, 2014).

This study uses quantitative research methods with descriptive and causal associative approaches, purpose to determint the influence of two or more variables (Sugiono, 2008). The purpose of this study is to build a theory that serves to explain a relationship. The relationship used is causal, namely, the relationship that influences one variable and another.

Sample is part of the number and the population characteristics of Sample who actually become in a research data, Taken by certain technique using a technique called some sample technique done purposively sample.

\section{RESULT AND DISCUSSION}

Multiple linear regression is used to test the relationship of more than one independent variables (explanatory) on one dependent variable and is generally show at equation:

\section{$\mathrm{CETR}=\mathrm{a}+\mathrm{b} 1$ ROAit $+\mathrm{b} 2$ DERit $+\mathrm{b} 3$ Sales growth $+\mathrm{e}$}

\section{Table 1. Multiple Linear Regression}

\begin{tabular}{|c|c|c|c|c|}
\hline \multicolumn{5}{|c|}{ Dependent Variable: CETR } \\
\hline \multicolumn{5}{|c|}{ Method: Least Squares Panel } \\
\hline \multicolumn{5}{|c|}{ Date: 07/25/20 Time: 14:49 } \\
\hline \multicolumn{5}{|c|}{ Sample: 20152018} \\
\hline \multicolumn{5}{|c|}{ Periods included: 4} \\
\hline \multicolumn{5}{|c|}{ Cross-sections included: 25} \\
\hline \multicolumn{5}{|c|}{ Total panel (balanced) observations: 100} \\
\hline Variable & Coefficient & Std. Error & t-Statistic & Prob. \\
\hline $\mathrm{C}$ & 0.014708 & 0.008981 & 1.637614 & 0.1048 \\
\hline ROA & 0.267435 & 0.095329 & 2.805378 & 0.0061 \\
\hline DER & -0.006704 & 0.005504 & -1.218070 & 0.2262 \\
\hline $\begin{array}{l}\text { SALES_- } \\
\text { GROWTH }\end{array}$ & 0.088982 & 0.024499 & 3.632090 & 0.0005 \\
\hline R-squared & 0.212467 & Mean depe & ndent var & 0.033020 \\
\hline $\begin{array}{l}\text { Adjusted } \\
\text { R-squared }\end{array}$ & 0.187856 & SD depend & ent var & 0.045103 \\
\hline $\mathrm{SE}$ of regression & 0.040647 & Akaike inf & criterion & -3.528615 \\
\hline $\begin{array}{l}\text { Sum squared } \\
\text { resid }\end{array}$ & 0.158608 & Schwarz cr & iterion & -3.424408 \\
\hline Log-likelihood & 180,4308 & Hannan-Qu & linn criter. & -3.486441 \\
\hline F-statistic & 8.633198 & Durbin-Wa & tson stat & 1,792175 \\
\hline $\begin{array}{l}\text { Prob } \\
\text { (F-statistic) }\end{array}$ & 0.000039 & & & \\
\hline
\end{tabular}

Source: Eviews Version 9 for Windows

Picture 1. Research design

Determinant Tax Avoidance in Basic and Chemical Industry Manufacturing Companies Listed on the IDX 
As seen on the table 1 above, we can say that the multiple linear regression result calculations are as follows:

$C E T R=0.014708 i t+0.267435$ ROAit-0.006704 DERit

+0.088982 SALES GROWTH + eit

From the regression model equation above, it can be interpreted as follows:

1. The constant is 0.014708 , meaning that if the return on assets, debt to equity ratio, and sales growth are not there or the value is 0 , then the cash effective tax rate is 0.014708 .

2. The regression coefficient of the return on assets variable is 0.267435 , meaning that if the return on assets is increased by 1 unit, then the return on assets will increase by 0.267435 units. The coefficient is positive, which means a direct effect between return on assets and the cash effective tax rate $(\mathrm{Y})$.

3 . The debt to equity ratio variable regression coefficient is -0.006704 , meaning that if the debt to equity ratio is increased by 1 unit, the debt to equity ratio will decrease by 0.006704 units. The coefficient is negative, meaning an opposite relationship between the debt to equity ratio and the cash effective tax rate $(\mathrm{Y})$.

4. The sales growth variable's regression coefficient is 0.088982 , meaning that if the

Sales Growth is increased by 1 unit, then the Sales Growth will increase by 0.088982 units. The coefficient is positive, meaning a unidirectional influence between Sales Growth and the cash effective tax rate

\section{Determination Coefficient Test}

Table 1 states that the adjusted R-Square value is 0.187856 , meaning that the coefficient of determination is 0.187856 . This states that the independent variable explains the dependent variable for $18.7856 \%$; the variables influence the remaining $81.2144 \%$.

\section{Significance Test of Partial Regression (t Statistical Test)}

The statistical t-test is shown how far the influence of one independent variable individually in explaining the variation of the dependent variable.

1. First Hypothesis (Ha1)

The partial regression significant test can be seen from the results of significance testing and t-test. The results can be seen in table 1 with the return on assets coefficient value of 0.267435 , which indicates that return on assets positively affects cash effective tax rate. The probability value is $0.0061<0.05$, which means that its growth has a significant effect on the cash effective tax rate.

2. Second Hypothesis (Ha2)

The partial regression significant test can be seen from the results of significance testing and t-test. The results can be seen in table 1 with the coefficient value of debt to equity ratio of -0.006704 , which indicates that the debt to equity ratio hurts the cash effective tax rate. The probability value is $0.2262>$ 0.05 , which means that the debt to equity ratio has no significant effect on the cash effective tax rate.

3. Third Hypothesis (Ha3)

For the partial regression, a significant test can be seen from the significance testing and t-test results. The results can be seen in table 1 with a sales growth coefficient value of 0.088982 , which indicates that company size positively influences the cash effective tax rate. The probability value is $0.0005<0.05$, which means that sales growth significantly affects the cash effective tax rate.

\section{Simultaneous Regression Significance Test (Test Statistic f)}

The multiple regression significance tests can be seen from the results of significance testing and the F test. The results can be seen in table 1 . The probability value is $0.000039<0.05$, which means that return on assets, debt to equity ratio, and sales growth together affect cash effectiveness. Tax rate.

\section{First Hypothesis (Ha1)}

Based on the research results, the effect of Profitability on Tax Avoidance shows that Profitability has a positive and significant effect on Tax Avoidance. This can be seen from the value of the partial test results (t-test) that the coefficient value of return on assets is 0.267435 , which shows that return on assets has a positive effect on cash effective tax rate and has a probability value of $0.0061<0.05$, which means that return on assets has a significant influence on cash effective tax rate. This study proves that the return on assets has a significant effect on the cash effective tax rate (Haw, Hu, Hwang, \& Wu, 2004).

Profitability is the size of the company performance. A company profitability show a company ability to produce profit during the being determined in certain levels with the sale, Assets, of capital stock .rasio it is and the return on asset (ROA) (Limakrisna \& Juju, 2008).

Return On Assets serves to measure the effectiveness of the company is using its resources. 
The higher the company's profitability, the higher the company's net profit. When companies' profits increase, the amount of income tax that should be paid to the State treasury will increase according to the increase in company profits. With the increase in company profits, the tendency of companies to practice tax avoidance is very high (Noor, 2011).

Every company has the same goal of making a profit. The company's management makes every effort to determine policies that can bring the company according to its expectations. According to (Erlangga \& Mawardi, 2016)liquidity, capital adequacy and financing fraud on Sharia Bank profitability in Indonesia by January 2010 until December 2014 period. Research using purposive sampling method for taking samples. Data obtained based on Bank of Indonesia published viaWebsite realtime, obtained 60 samples. Research variables consisted of four independent variables and 1 dependent variable. Data analysing technique to answer research problem and examine research hypothesis using Double Linear Regression Analysis that supported by SPSS Statistics version 20 application. Based on the research, known that the effect of firm size (asset total, the ratio of advantage is its ability to profit for sale, assets and this capital with long-term investors will be interested in this analysis Good profitability.

\section{Second Hypothesis (Ha2)}

Based on the research results, the effect of Leverage on Tax Avoidance shows that Leverage has a negative and insignificant effect on Tax Avoidance. This can be seen from the value of the partial test results (t-test) that the coefficient value of the debt to equity ratio is -0.006704 , which indicates that the debt to equity ratio hurts the cash effective tax rate and has a probability value of $0.2262>0.05$, which means debt to equity ratio does not have a significant effect on the cash effective tax rate. This study proves that DER does not have a significant effect on the cash effective tax rate (Handayani sri, fariyanti anna, 2016).

Leverage is an increase in the amount of debt that results in additional spending items in the form of interest or interest to reduce the company's taxable income. The higher of the leverage the ratio, the higher of the number of third party funds from debt used by the company, and the higher of the interest costs arising from this debt. Flowers cost higher will give effect of reducing the tax charge. The higher of the corporate leverage value, The higher of the act of corporate tax avoid. The result of debts in view interest costs can be a reduced an allowance for taxable, the According to law no.36, 2008 income of taxes and article 61 a number 3 .
However, in this study, Leverage does not affect tax avoidance because companies do not use debt to reduce the tax burden and finance company operations (Kurniasih, Fidowaty, \& Sukaesih, 2013).

According to (Nelson, 2014), the ratio increased a ratio describing the relationship between debt and capital, this ratio measure how much companies financed by obligation or external sides with described by capital, according to the (Rampini \& Viswanathan, 2013) the leverage is used to measure the extent to which the company assets are funded. Debt rasio is used for measuring its ability to pay for all both short term and long term debts / total assets.

In practice, to cover the shortage of the needed funds, the company has several sources of funds that can be used one financial resources used is capital loans debt. Capital debt relatively not limited and motivate management to work more creative and active in, because should pay their obligations dangerous products (Fernandes et.al., 2014). Instrument is used in analyze financial report to show the amount of collateral to creditors available.

\section{Third Hypothesis (Ha3)}

Based on the research results, the effect of Sales Growth on Tax Avoidance shows that Sales Growth has a positive and significant effect on Tax Avoidance. This can be seen from the value of the partial test results (t-test) that the Sales Growth coefficient value is 0.088982 , which shows that Sales Growth has a positive effect on the cash effective tax rate and has a probability value of $0.0005<0.05$, which means that Sales Growth has a significant effect on cash effective tax rate. This study proves that sales growth has a significant effect on the cash effective tax rate (Ahmad, Salim, Ean, Isa, \& Fong, 2003).

The increase in the company's sales growth can indicate that the company's profitability is also increasing. As profitability increases, corporate tax payments will also increase. Based on agency theory, agents will tend to be able to reduce their tax costs because it can affect the compensation that will be obtained because sales growth can be used to predict how much profit will be obtained so that agents can carry out tax management so that the profits they get remain maximum.

According to (Walter, Auer, \& Ritter, 2006), sales growth is an important indicator of the market acceptance of products and service. So will obtained amount of income resulting from the sale could be used to measure the growth rates sales. Sales growth reflect the past investment successes and can be used as a prediction growth. For the growth sales is also an indicator of a company's demand and competitiveness in the industry. 


\section{Fourth Hypothesis (Ha4)}

Profitability, Leverage, and Sales Growth has a probability value of $0.000039<0.05$, which means that together it affects the Cash Effective Tax Rate. The adjusted R-Square value is 0.187856 , meaning that the coefficient of determination is 0.187856 . This states that the independent variable explains the dependent variable of $18.7856 \%$, the remaining $81.2144 \%$ is influenced by other variables such as Company Size, Company Age, Institutional Ownership, Audit Committee, and others (Sarma \& Pais, 2011).

Every company has the same goal of making a profit. The company's management makes every effort to determine policies that can bring the company according to its expectations. According to (Erlangga \& Mawardi, 2016)liquidity, capital adequacy and financing fraud on Sharia Bank profitability in Indonesia by January 2010 until December 2014 period. Research using purposive sampling method for taking samples. Data obtained based on Bank of Indonesia published viaWebsite realtime, obtained 60 samples. Research variables consisted of four independent variables and 1 dependent variable. Data analysing technique to answer research problem and examine research hypothesis using Double Linear Regression Analysis that supported by SPSS Statistics version 20 application. Based on the research, known that the effect of firm size (asset total, the ratio of advantage is its ability to profit for sale, assets and this capital with long-term investors will be interested in this analysis Good profitability.

According to (Nelson, 2014), the ratio increased a ratio describing the relationship between debt and capital, this ratio measure how much companies financed by obligation or external sides with described by capital, according to the (Rampini \& Viswanathan, 2013) the leverage is used to measure the extent to which the company assets are funded. Debt rasio is used for measuring its ability to pay for all both short term and long term debts / total assets.

In practice, to cover the shortage of the needed funds, the company has several sources of funds that can be used one financial resources used is capital loans debt. Capital debt relatively not limited and motivate management to work more creative and active in, because should pay their obligations dangerous products (Fernandes et.al., 2014). Instrument is used in analyze financial report to show the amount of collateral to creditors available.

According to (Walter, Auer, \& Ritter, 2006), sales growth is an important indicator of the market acceptance of products and service. So will obtained amount of income resulting from the sale could be used to measure the growth rates sales. Sales growth reflect the past investment successes and can be used as a prediction growth. For the growth sales is also an indicator of a company's demand and competitiveness in the industry.

\section{CONCLUSION}

Leverage, and sales growth have a significant effect on taxes avoid crude and industrial chemical manufacturing companies registered at the indonesian stock exchange 2015-2018. Profitabilitas variable have a significant effect on taxes avoid in element and chemical manufacturing companies listed on the stock exchange for the period indonesia 20152018. Leverage do not have significant effect on taxes avoid in crude and industrial chemical manufacturing companies listed on the stock exchange for the period indonesia 2015-2018. Sales growth have a significant effect on taxes avoid crude and chemical manufacturing companies listed on the stock exchange for the period indonesia 20152018. Variable the effects of profitability are leverage and sales growth in tax crude and chemical avoid industry manufacturing companies listed on the stock exchange for the period indonesia 2015-2018

\section{REFERENCE}

Ahmad, A., Salim, K., Ean, C., Isa, M. \& Fong, L. (2003). An overview of the socioeconomic status of fisheries in Malaysia. WorldFish Center Conference Proceedings.

Aulia, F. (2016). Pengaruh Car, Fdr, Npf, Dan Bopo Terhadap Profitabilitas (Return On Equity) (Studi Empiris pada Bank Umum Syariah di Indonesia Periode Tahun 2009-2013 ). Diponegoro Journal Of Management, 5, (6), 1-10. Retrieved from http://ejournal-s1.undip. ac.id/index.php/djom

Australian Bureau of Statistics. (2016). Employee Earnings and Hours, Australia 2016. Retrieved from. https://www. abs.gov.au/AUSSTATS/abs@.nsf/ Lookup/6306.0Main+Features 1May\%20 2016? OpenDocument

Dimitrios, A., Helen, L. \& Mike, T. (2016). Determinants of non-performing loans: Evidence from Euro-area countries. Finance Research Letters. 18, 116-119. https://doi. org/10.1016/j.frl.2016.04.008

Erlangga, O.P., \& Mawardi, I. (2016). Pengaruh Total Aktiva, Capital Adequacy Ratio (Car), Finance To Deposit Ratio (Fdr) Dan Non 
Performing Financing (Npf) Terhadap Return on Assets (Roa) Bank Umum Syariah Di Indonesia Periode 2010-2014. Jurnal Ekonomi Syariah Teori Dan Terapan, 3, (7), 561-574. https://doi.org/dx.doi.org/10.20473/ vol3iss20167pp561

Fernandes, D., Lynch, J.G. \& Netemeyer, R.G. (2014). Financial literacy, financial education, and downstream financial behaviors. Management Science. 60, (8), 1861-1883. https://doi.org/10.1287/mnsc.2013.1849

Fitriyanti, I., Fauzi, A. \& Armeliza, D. (2017). Pengaruh Ketepatan Pengalokasian, Teknologi dan Informasi Perpajakan, dan Diskriminasi Terhadap Penggelapan Pajak (Tax Evasion). Ilmiah Wahana Akutansi, 12, (01), 84-104.

Grant, J. L. (2003). Foundations of Economic Value Added. The Frank J. Fabozzi series.

Handayani, S., Fariyanti, A. \& Nurmalina, R. (2016). Swasembada Daging Sapi Analisis Simulasi Ramalan Swasembada Daging Sapi Di Indonesia. Sosiohumaniora. 18, (1), 61-70.

Haw, I.M., Hu, B., Hwang, L.S. \& Wu, W. (2004). Ultimate ownership, income management, and legal and extra-legal institutions. Journal of Accounting Research. 42, (2), 423-462. $\quad$ https://doi.org/10.1111/j.1475679X.2004.00144.X

Kostini, N., Dai, R.M., \& Oktaviani, D.R. (2017). Comparative Analysis Of Financial Performance Pt Kalbe Farma, Tbk. And Pt Kimia Farma (Persero) Tbk Using Du Pont System In 2012-2014. AdBispreneur. 2, (1), 19-30. https://doi.org/10.24198/adbispreneur. v2i1.12919

Kraak, V.I., Harrigan, P.B., Lawrence, M., Harrison, P.J., Jackson, M.A. \& Swinburn, B. (2012). Balancing the benefits and risks of publicprivate partnerships to address the global double burden of malnutrition. Public Health Nutrition. 15, (3), 503-517https://doi. org/10.1017/S1368980011002060

Kurniasih, D., Fidowaty, T. \& Sukaesih, P. (2013). Pengaruh Implementasi Kebijakan E-Government Terhadap Kinerja Aparatur Kota Cimahi. Sosiohumaniora. 15, (1), 6-14. https://doi.org/10.24198/sosiohumaniora. v15i1.5234

Limakrisna, N. \& Juju, U. (2008). Pengaruh Sinergi, Kredibilitas, Kepemilikan Baru, Budaya, Tata
Kelola Perusahaan pada Kinerja Bank Pasca Privatisasi. Trikonomika, 7, (2), 97-105.

Makri, V., Tsagkanos, A. \& Bellas, A. (2014). Determinants of non-performing loans: The case of Eurozone. Panoeconomicus. 61, (2), 193-206 https://doi.org/10.2298/PAN1402193M

Muriithi, J.G., Wanjau, K. \& Omondi, H. (2018). Performance of Incubator Centres in Kenya. International Journal of Research in Business and Social Science. 7, (1), 49-59. https://doi. org/10.20525/ijrbs.v7i1.859

Nelson, A.J. (2014). From the ivory tower to the startup garage: Organizational context and commercialization processes. Research Policy. 43, (7), 1144-1156. https://doi. org/10.1016/j.respol.2014.04.011

Noor, Z.Z. (2011). Penyebab Economic Exposure Pada Perusahaan Manufaktur Go Public Di Bursa Efek Indonesia. Sosiohumaniora. 13, (2), 211-222. https://doi.org/10.24198/ sosiohumaniora.v13i2.5517

Rampini, A.A. \& Viswanathan, S. (2013). Collateral and capital structure. Journal of Financial Economics. 109, (2), 466-492. https://doi. org/10.1016/j.jfineco.2013.03.002

Reschiwati, Limakrisna, N., Sayekti, F. \& Purnamasari, M.A. (2019). Data panel regression: Effect of company risk, company size, and tax profitability for tax avoidation (empirical study on property and real estate companies listed on the Indonesia stock exchange for the period 2013-2017). Test Engineering and Management. 81, (November-December 2019), 3636-3649.

Sarma, M. \& Pais, J. (2011). Financial inclusion and development. Journal of International Development. 23, (5), 613-628. https://doi. org/10.1002/jid.1698

Simatupang,A.\&Franzlay,D.(2016).Capital Adequacy Ratio(CAR), Non Performing Financing (NPF), Efisiensi Operasional (BOPO) dan Financing to Deposit Ratio (FDR) Terhadap Profitabilitas Bank Umum Syariah di Indonesia. Administrasi Kantor, 4, (2), 466- 485.

Stavins, R.N. (2000). Market-based environmental policies. Public policies for environmental protection.

Sugiono. (2008). Metode penelitian pendidikan: (Pendekatan Kuantitatif, Kualitatif dan R \& D). Bandung : Alfabeta 
Vatansever, M. \& Hepsen, A. (2015). Determining Impacts on Non-Performing Loan Ratio in Turkey. Journal of Applied Finance and Banking. 5, (1), 1-11.

Walter, A., Auer, M. \& Ritter, T. (2006). The impact of network capabilities and entrepreneurial orientation on university spin-off performance. Journal of Business Venturing,
21, (4), 541-567. https://doi.org/10.1016/j. jbusvent.2005.02.005

Zango, A. G., Kamardin, H. \& Ishak, R. (2015). Mandatory International Financial Reporting Standards 7 (IFRS 7) Disclosure by Listed Banks in Nigeria. Academic Journal of Interdisciplinary Studies. 4, (2), 435-440. https://doi.org/10.5901/ajis.2015.v4n2p435 